\title{
The competencies of the shift leader in the intensive care unit setting, in a private hospital group in South Africa
}

Authors:
Elzabé Nel $^{1}$
Ann Müller
Adele Colyn'
Affiliations:
'Department of Nursing
Science, University of
Johannesburg, South Africa
Correspondence to:
Elzabé Nel
Email:
ewnel@uj.ac.za
Postal address:
PO Box 524, Auckland Park
2006, South Africa
Dates:
Received: 24 July 2008
Accepted: 22 Sept. 2010
Published: 29 Mar. 2011
How to cite this article:
Nel, E., Müller, A. \&
Colyn, A., 2011, 'The
competencies of the shift
leader in the intensive
care unit setting, in a
private hospital group
in South Africa', Health
SA Gesondheid $16(1)$,
Art. \#425, 10 pages.
doi:10.4102/hsag.v16i1.425

(C) 2011. The Authors. Licensee: OpenJournals Publishing. This work is licensed under the Creative Commons Attribution License.
Newly qualified intensive care nurses are forced into positions of authority and responsibility as shift leaders at an early stage and are not given a chance to consolidate their new knowledge with practice. They have to be responsible and accountable not only for their own actions, but also for those of their staff. The purpose of this study was to explore and describe the competencies of the shift leader in the intensive care unit setting to determine whether there is a gap between what is expected of the shift leader and what is happening in reality. A quantitative, descriptive design was used and cluster sampling was implemented. Questionnaires were used to gather data from three clusters, comprising 11 hospitals from a single private hospital group. Of the 251 questionnaires that were handed out to intensive care personnel (including trained and non-trained staff), 98 were returned, resulting in a response rate of $39 \%$. An in-depth literature study and submission of questionnaires to experts before being administered to respondents ensured validity and reliability. Results were used to describe a typology of the competencies of the shift leader in the intensive care setting and indicated that respondents classified competencies related to the application of the nursing process in the intensive care unit in all its facets as essential competencies. None were classified as a critical competency and only four were classified as specific competencies. All respondents in the three clusters regarded their shift leaders as competent.

Pas-gekwalifiseerde, intensiewesorg-verpleegkundiges word op 'n vroeë stadium as skofleiers in posisies van gesag en verantwoordelikheid geplaas en word nie die kans gegun om hul nuwe kennis met die praktyk te konsolideer nie. Tog moet hulle verantwoordelikheid en aanspreeklikheid aanvaar nie net vir hul eie aksies nie, maar ook vir dié van hul personeel. Die doel van hierdie studie was om die vaardighede van skofleiers in die opset van die intensiewesorg-eenheid te ondersoek en te beskryf om te bepaal of daar'n gaping bestaan tussen wat van hulle verwag word en wat in werklikheid gebeur. ' $n$ Kwantitatiewe, beskrywende ontwerp is gebruik en ' $n$ trossteekproef is geïmplementeer. Vraelyste is gebruik om data in te samel van drie trosse bestaande uit 11 hospitale van ' $n$ enkele privaathospitaalgroep. Van die 251 vraelyste wat uitgedeel is aan intensiewesorg-personeel (insluitend opgeleide en nie-opgeleide personeel), is 98 terugontvang, wat vertaal na 'n responskoers van 39\%. 'n Diepgaande literatuurstudie en voorlegging van vraelyste aan deskundiges voordat dit aan respondente uitgedeel is, het bygedra tot geldigheid en betroubaarheid. Resultate is gebruik om ' $n$ tipologie van die vaardighede van skofleiers in 'n intensiewesorg-eenheid te beskryf en dit het geblyk dat respondente die vaardighede wat verband hou met die verpleegproses in die intensiewesorg-eenheid in al sy fasette as noodsaaklike vaardighede klassifiseer. Geen vaardigheid is as kritiek geklassifiseer nie en slegs vier vaardighede is as spesifieke vaardighede geklassifiseer. Al die respondente in die drie trosse het hul skofleiers as vaardig beskou.

\section{Introduction}

The shift leader is responsible for adequately addressing problems concerning personnel management and the general functioning of the unit. In an intensive care unit where the acuity level and severity of the patients' condition are high and constantly changing, the shift leader is also expected to make complex clinical decisions regarding the treatment of the critically ill patient (Muller 2002:200; Scribante \& Bhagwanjee 2007:67).

A study by Scribante, Schmollgruber and Nel (2004:113) showed that only $25 \%-50 \%$ of nurses working in intensive care units are trained to nurse critically ill patients. This implies that $50 \%-75 \%$ of nurses do not have the necessary training to give critically ill patients the required standard of care. The shift leader, who should be trained for intensive care, will therefore be 
the person making the relevant decisions in the case where nurses who have not been trained in intensive care are nursing a critically ill patient.

Without adequate supervision by a shift leader the quality of care may decline dramatically. However, adequate supervision by the shift leader ensures proper nursing care and prevents things from going wrong (Booyens 2001:301).

\section{Background}

An increasing number of trained intensive care nurses are leaving the profession (DENOSA 2006:42-43). The result of the decreased numbers in experienced intensive care trained nurses is that newly qualified intensive care nurses assume the duty of shift leaders in the intensive care units. These newly qualified intensive care nurses are registered as competent in clinical intensive care nursing, but not in the knowledge and skills required to lead a shift in an intensive care unit. The required knowledge and skills can be gained only over time and from experience working in intensive care units.

Because the shift leader assumes responsibility for all the staff working on that shift, as well as all the patients in the unit and decisions about their treatment, it is crucial that their functions must be performed competently. Numerous newly qualified nurses have complained that the responsibility of being a shift leader is excessive. They complain that they cannot cope; they have become burnt out and have lost their enthusiasm to care for critically ill patients. The number of court cases and disciplinary hearings involving shift leaders (Ka Mzolo 2005:26-29) underlines the fact that the shift leaders' competencies might not be up to standard.

\section{Problems statement}

The exact competencies of shift leaders have not been clearly identified or described and each unit, as a result of varying specialities (e.g. cardiothoracic or neurosurgery), requires different competencies of the shift leader. Hospital and nursing management also require more and more competencies of the shift leaders as they demand a wellfunctioning unit regardless of the number of trained intensive care staff. This causes uncertainty and unhappiness on the part of the shift leaders.

The following question emerged when looking at this problem from a shift leader's perspective: what clinical competencies are essential, critical and specific to shift leaders in the intensive care setting and how competent are shift leaders in these functions?

\section{Purpose and objectives of the study}

The purpose of this study was to explore and describe the competencies of the shift leader in the intensive care unit setting.

The research objectives were to:

- describe the essential, critical and specific clinical competencies of the shift leader in the intensive care unit
- explore and describe the gap between expected and actual competency of the shift leader in the intensive care unit

- describe a typology of the competencies needed by shift leaders in the intensive care unit.

\section{Literature review}

The shift leader is seen as the professional nurse in charge of the shift (Krugman \& Smith 2003:285) and is responsible for overseeing the efficient functioning of the nursing unit (Hughes \& Kring 2005:16). To achieve this, the shift leader delegates tasks and supervises the nursing care of all the nurses (Morris 2004:16; Suominen et al. 2005:147). Because shift leaders are continuously at the centre of everything happening in the unit, it is imperative that they should be competent practitioners.

The World Health Organization states that competency requires knowledge, the appropriate attitudes and observable mechanical and intellectual skills (Hanley \& Higgins 2005:270). The South African Nursing Council's Charter of Nursing Practice (2004) broadly defines competence as a 'level of performance, demonstrating the effective application of knowledge, skills, judgement and personal attributes required to practice safely and ethically in a designated role and setting'. Elliott, Aitken and Chaboyer (2007:167) refer to competence as an important dimension of nursing practice as it provides the nursing services with confidence in the knowledge, skill and attitudes that nurses must have to be safe practitioners.

Different definitions of competence always show interplay between interpersonal and technical skills and critical thinking, thereby integrating cognitive, affective and psychomotor domains of nursing practice (Meretoja, Isoaho \& Leino-Kilpi 2004:125). Mollerup and Mortensen (2004:72) go a step further and distinguish between formal and real competencies. Formal competencies refer to assumed competence of a nurse due to qualifications. These are the competencies of a newly qualified nurse. Real competence refers to the ability to apply knowledge, practice and skills together with the appropriate attitudes in a specific situation. Magobe (2005:20) defines competence as the notion of real competence, implying the integration of theory and practice.

Locsin (1998:52) further divides real competencies into essential, critical and specific competencies.

- Essential competencies reflect on the shift leader, like staff delegation and communication with the multidisciplinary team.

- Critical competencies are best seen in a situation where rapid interventions are required, for example cardiac resuscitation.

- Specific competencies are unique to a specific unit, for example nursing a patient on an intra-aortic balloon pump as is typically done in a cardiac intensive care unit.

As competency is a complex term it is necessary to describe further the functions in which the shift leader should be competent. McEwen, Cooper and Clayworth (2005:39) 
describe the functions of the shift leader as managerial, educational and clinical. At managerial level, the shift leader is responsible for organising and managing personnel in the unit, as well as solving problems through the use of the decision-making process (Muller 2002:130-139). The educational competency of shift leaders refers to their involvement in creating a conducive learning environment and actively involving nursing students, colleagues and patients in learning activities (Arvidsson \& Fridlund 2005:235). Clinical competency entails nursing a critically ill patient and the different clinical nursing interactions involved in providing a safe environment 24 hours a day (Muller 2002:175; Elliott et al. 2007:10).

Morris (2004:16) identifies several responsibilities of the shift leader, namely assessment and diagnosis of the patient, followed by planning, implementation and evaluation of patient care.

\section{Assessment}

Assessment may be seen as collecting data of a patient and using the information to make decisions about the care, support or intervention that is required (Van Rooyen \& Jordan 2009:316). According to Elliot et al. (2007:114), advanced clinical assessment skills are essential for the critical care nurse as the data that are collected are important to identify the immediate and future needs of the patient and thereby facilitate the development of a comprehensive care plan.

Four main assessment techniques are used, namely inspection, palpation, percussion and auscultation. Inspection includes a systematic, deliberate and focused visual examination, comparing what is seen with what is already known. Palpation is examination of the body using touch. Percussion refers to using finger tapping to elicit different sounds that will reveal details about underlying areas. Auscultation refers to listening to sounds with a stethoscope (Elliot $e t$ al. 2007:114)

Assessment is an ongoing process as the nurse continuously assesses the response of the patient (Van Rooyen \& Jordan 2009:15).

\section{Diagnosing}

The diagnostic process uses the critical thinking skills of analysis and synthesis (Berman et al. 2008:199). Arries (2002:229) refers to diagnosing as the intellectual activity during which critical thinking processes are used to identify patterns in the assessment data to reach a conclusion. To formulate a nursing diagnosis entails three steps: analysing data gathered during the assessment, identifying health problems, risks and strengths and then formulating the diagnosis (Berman et al. 2008:199). The nurse working in the intensive care unit is responsible for diagnosing any health needs that the patient may experience and planning their care accordingly. The shift leader should be able to check the diagnosis made by the nurse and, in the case of problems, be able to anticipate potentially fatal complications and intervene to prevent them. It is imperative for the well-being of the patient that the correct diagnosis be made (Bakalis 2006:39; Huggins 2004:38).

\section{Planning}

After a purposeful assessment of goals for care, the shift leader plans how they will be achieved. Planning demands the application of certain reasoning skills, critical analysis, prioritising, decision-making and problem-solving skills (Muller 2002:132). Achievable goals for the shift are also formulated during this phase (Berman et al. 2008:211).

To achieve these goals the shift leader identifies, mobilises and organises the nursing staff and resources. This is one of the most important phases in the shift leader's day, as optimal, safe nursing care will be provided if it is done competently. Hoban (2003:80) emphasises that it is crucial to delegate patients according to the competency level of the nurses as this will ensure quality nursing care.

Muller (2002:133) reiterates that good planning is one of the prerequisites for achieving goals set in an intensive care unit.

\section{Implementation}

The implementation of the nursing care plan involves putting the plan into action in order to achieve the set goals and objectives (Arries 2002:250).

In the critical care units, nurses are expected to work to many standards, guidelines, protocols and current evidence-based practices that are related to patient care (Elliott et al. 2007:187) and it is the shift leader's duty to oversee that the nurses adhere to these standards.

During implementation of the plan the nurses need cognitive, interpersonal and technical skills. The cognitive skills include problem solving, decision making, critical thinking

\begin{tabular}{|c|c|c|}
\hline \multirow[t]{2}{*}{ Region } & \multicolumn{2}{|c|}{ Total number } \\
\hline & Professional nurses & Shift leaders \\
\hline \multicolumn{3}{|l|}{ Tshwane } \\
\hline Hospital $A^{\ddagger}$ & 41 & 24 \\
\hline Hospital B ${ }^{+}$ & 13 & 11 \\
\hline Hospital C ${ }^{\dagger}$ & 22 & 6 \\
\hline Hospital $D^{\ddagger}$ & 28 & 14 \\
\hline Total & 104 & 55 \\
\hline \multicolumn{3}{|c|}{ Johannesburg } \\
\hline Hospital E ${ }^{\ddagger}$ & 24 & 7 \\
\hline Hospital F ${ }^{\dagger}$ & 30 & 12 \\
\hline Hospital G ${ }^{\ddagger}$ & 37 & 12 \\
\hline Total & 91 & 31 \\
\hline \multicolumn{3}{|l|}{ Cape Town } \\
\hline Hospital H ${ }^{+}$ & 6 & 4 \\
\hline Hospital I ${ }^{+}$ & 17 & 8 \\
\hline Hospital J ${ }^{+}$ & 13 & 4 \\
\hline Hospital K ${ }^{5}$ & 20 & 10 \\
\hline Total & 56 & 26 \\
\hline
\end{tabular}

one intensive care unit; ${ }^{\ddagger}$, two intensive care units; ${ }^{\varsigma}$, three intensive care units. 
and creativity. Interpersonal skills are all the activities, both verbal and non-verbal, that are used to interact with one another. Good communication and multiprofessional collaboration are vital in providing holistic care for the patient in the intensive care unit. Technical skills are purposeful skills such as operating equipment. Nurses choose one or more actions that will be effective to achieve the goals that were set. These decisions are usually based on knowledge and experience (Berman et al. 2008:223, 224, 233; Van Rooyen \& Jordan 2009:325; Elliott et al. 2007:187).

\section{Evaluation}

The evaluation of a patient may be seen as a planned, ongoing and purposeful activity during which the intensive care nurse and shift leader determine whether the patient is making progress towards recovery. Evaluation is continuous and should be done while a nursing intervention is being implemented, or directly afterwards, to allow the nurse to make on-the-spot modifications. Noting the reaction of the patient to treatment can make the difference between life and death (Berman et al. 2008:235).

To enable the shift leader to be competent, leadership skills are essential. Leadership may be seen as a multifaceted process, with the leader showing skills such as approachability, motivating team members, creating a learning environment, promoting autonomy amongst staff and managing conflict situations (Davidson, Elliott \& Daly 2006:182; Mathena 2002:140; Berggren \& Severinsson 2003:616).

Intensive care nurses are exposed to rapidly expanding medical technologies, which brings certain ethical dilemmas (Le Blanc et al. 2001:461). The shift leader should be competent in clinical decision making in a situation with ethical consequences, like identifying organ donors or protecting patients during clinical research trials. Byers (2004:52) states that patients in the intensive care area are exceedingly vulnerable from a research perspective and may, because of cognitive impairment, depend on members of the health care team to protect their interests.

\section{Research design Research approach and method}

A quantitative descriptive design was used to describe the essential, critical and specific clinical competencies of the shift leaders in the intensive care unit and to explore and

TABLE 2: Layout of the questionnaire.

\begin{tabular}{|c|c|}
\hline Section & Description \\
\hline \multicolumn{2}{|l|}{ Section A } \\
\hline Biographical and other relevant data & $\begin{array}{l}\text { Information regarding biographical data, level of qualifications and experience were requested, as well as data regarding the } \\
\text { units in which respondents were working at the time. }\end{array}$ \\
\hline Section B & Assessment, including items such as: \\
\hline \multirow[t]{10}{*}{$\begin{array}{l}\text { Clinical competencies of the shift leader, organised } \\
\text { according to the nursing process }\end{array}$} & $\begin{array}{l}\text { - knowledge regarding theoretical and related concepts } \\
\text { - initial assessment, including physical examinations, laboratory results and chest X-rays } \\
\text { - basic needs, including hygiene, feeding status, social needs and safety } \\
\text { - reading blood pressure, cardiac rhythm, central venous pressure (CVP), oxygen saturation, pulmonary artery pressure, } \\
\text { pulmonary artery wedge pressure, extradural pressure and intracranial pressure from monitors } \\
\text { - recognition of complications from data on monitors. }\end{array}$ \\
\hline & Diagnosis, including items such as: \\
\hline & $\begin{array}{l}\text { - keeping abreast of the latest developments } \\
\text { - correct diagnosis after assessment } \\
\text { opening an airway and maintaining circulation. }\end{array}$ \\
\hline & $\begin{array}{l}\text { Planning, including items such as: } \\
\text { - delegating staff } \\
\text { - planning care } \\
\text { - prioritising problems } \\
\text { - mobilising staffing and material resources. }\end{array}$ \\
\hline & Implementation, including items such as: \\
\hline & $\begin{array}{l}\text { - implementing the plan of care } \\
\text { - implementing medication regimens } \\
\text { - communicating with the multidisciplinary team and patients' family } \\
\text { - assisting with advanced procedures (insertion of CVP, pulmonary artery and arterial lines, as well as removal of intra- } \\
\text { - aortic balloon pump) } \\
\text { - performing advanced procedures (haemodialysis, adjusting ventilator settings, removal of sheaths) } \\
\text { - nutritional strategies (enteral and parenteral). }\end{array}$ \\
\hline & $\begin{array}{l}\text { Evaluation, including items such as: } \\
\text { - evaluation of care } \\
\text { - calling for assistance in good time. }\end{array}$ \\
\hline & Recording, including items such as \\
\hline & $\begin{array}{l}\text { - criteria for record keeping } \\
\text { - keeping complete records. }\end{array}$ \\
\hline & $\begin{array}{l}\text { - leadership skills (approachability, motivating team members, creating a learning environment, promoting autonomy, } \\
\text { managing conflict, communication skills) } \\
\text { - ethical considerations (identifying organ donors, assisting with brain death testing and protecting patients during clinical } \\
\text { trials). }\end{array}$ \\
\hline
\end{tabular}


describe the gap between expected and actual competency of the shift leader in the intensive care unit. Quantitative studies may be seen as the study of a phenomenon that lends itself to precise measurement (Polit, Beck \& Hungler 2001:469). Descriptive study designs may be used to gain more information regarding the characteristics of a certain topic (Burns \& Grove 2005:232).

\section{Population and sampling}

The population of a study sets boundaries on the study. A population therefore refers to a specific set of individuals or organisations with specific characteristics that are going to be used in the study (De Vos 2002:198). The population of this study was all categories of nurses working in intensive care units. The target population was all professional nurses working in the intensive care units of a private hospital group in South Africa. Owing to the competitiveness of private hospital groups, permission could be obtained from only one hospital group.

Burns and Grove (2005:730) define a sample as the 'subset of the population that is selected for a study'. Therefore, the sample is that element of the population that is included in the study (De Vos 2002:199). Cluster sampling was used, as the target population was large and spread over a wide geographical area (Rossouw 2003:112). Three distinct clusters, namely the Tshwane, Johannesburg and Cape Town regions, were chosen as the private hospital group has the largest presence in these regions. A region was viewed as a cluster and a total sample was drawn from each cluster.

In total 251 questionnaires were handed out to professional nurses (whether trained for intensive care or not). Of the nurses trained for intensive care, 112 functioned as shift leaders. The actual sample at the time of fieldwork was 98 because this is the number of completed questionnaires that were returned.

\section{Data collection}

Information regarding the competencies of the shift leader in the intensive care unit setting were gathered during a survey. A questionnaire was selected as the most suitable method of data collection in the study. The questionnaire developed by $\mathrm{Nel}$ and Uys (1993) was adapted for use in this study after an extensive literature review on the topic. The layout of the questionnaire is shown in Table 2. The questionnaire comprised two sections, with the second being subdivided into seven parts.

The self-administered questionnaires were distributed among shift leaders and non-shift leaders in the selected intensive care units. If the researcher could not distribute the questionnaires personally, the nursing managers were asked to distribute them among the intensive care nurses. This situation applied mostly to the Cape Town region. A specific time for collection was given to each participant. The nursing managers were asked to return the questionnaires by post.

Scaling of the questionnaire: A Likert scale was used to determine the extent to which participants agreed with the statements. Questions were asked regarding the competence of the shift leader with reference to the described functions. Participants were also asked to indicate whether they thought the mentioned competence was essential, critical or specific in nature.

Pilot study: A pilot study was used to determine the precision of the questionnaire in establishing the unique functions of the shift leader in the intensive care setting. Ten intensive care nurses, who would not be participating in the final study, were asked to participate in the pilot study. Six completed questionnaires were returned. The participants indicated that the questionnaire was unambiguous and easy to complete. The covering letter was changed slightly to let the definitions of the three types of competency stand out more.

\section{Data analysis}

Data were analysed with the Statistical Package for the Social Sciences (SPSS) version 15.0. Descriptive statistics were performed to explore the data regarding clinical, essential, critical and specific competencies. Data were also analysed to detect the gap between expected and actual competency of the shift leader in the intensive care unit.

\section{Ethical considerations}

Ethical measures as set out by the Democratic Nurses Association of South Africa (DENOSA) were adhered to during the research process and included informed consent, confidentiality and anonymity, and protection from psychological harm (DENOSA 1998:3-7).

All ethical considerations, including autonomy, privacy, beneficence and freedom from harm, were applied according to the ethical standards proposed by the University of Johannesburg (clearance reference number 48/07).

\section{Validity and reliabilty Measures to ensure validity and reliability}

Validity refers to the extent to which the research conclusions correspond to reality (Burns \& Grove 2005:377-379).

\section{Internal validity}

In this study, internal validity was ensured by:

- implementing a pilot study

- complying with ethical standards during data collection

- maintaining principles of neutrality

- using an appropriate method of data analysis, namely descriptive statistics.

\section{Validity of the measuring instrument}

The following measures ensured that validity of the questionnaire used in this study was maintained.

Face validity: Face validity describes whether the instrument in reality measures what it 'appears' to measure (De Vos 2002:167). In this study: 


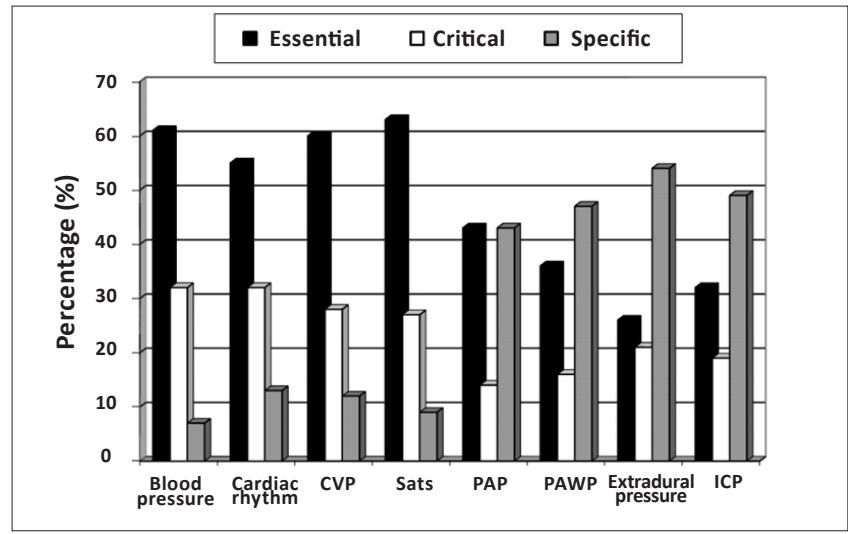

CVP, central venous pressure; Sats, oxygen saturation; PAP, pulmonary artery pressure; PAWP, pulmonary artery wedge pressure, ICP, intracranial pressure.

FIGURE 1: Readings from monitors as essential or specific competencies $(n=98)$.

- a pilot study was conducted.

- experts in the intensive care field were asked to review the questionnaire before it being administered to respondents (Rossouw 2003:124).

Content validity: The questionnaire should sample the full range of information represented by the theoretical concepts that are tested. The researcher worked towards content validity by:

- compiling a complete literature review regarding the components to be assessed

- presenting the questionnaire to experts to determine the content validity with regard to measurement outcomes.

\section{Reliability}

Reliability demonstrates the consistency of the measurement (Rossouw 2003:122). In this study, reliability refers to the accuracy with which the questionnaire measured what it was supposed to measure. Reliability was ensured by using the same questionnaire in all the hospitals and involving fieldworkers (primarily unit managers in distant hospitals). The researcher was available for assistance or questions during the research process.

\section{Results and discussion \\ General information regarding respondents}

The majority of respondents $(90 \%, n=88)$, were female, as can be expected in a female-dominated profession. Most respondents $(n=60)$ were between 30 and 44 years of age. Only $60 \%(n=59)$ of all respondents indicated that they were trained for intensive care.

Almost 32\% of respondents $(n=31)$ had between 5 and 9 years' experience in the intensive care setting, while a further $30 \%(n=29)$ had between 1 and 4 years' experience.

Some $48 \%$ of respondents $(n=47)$ worked in a multiintensive care setup, with the remaining respondents working in specialised intensive care units like cardiac or trauma intensive care units. Fifty-six per cent of respondents $(n=55)$ worked in an intensive care unit with between nine and twelve beds.

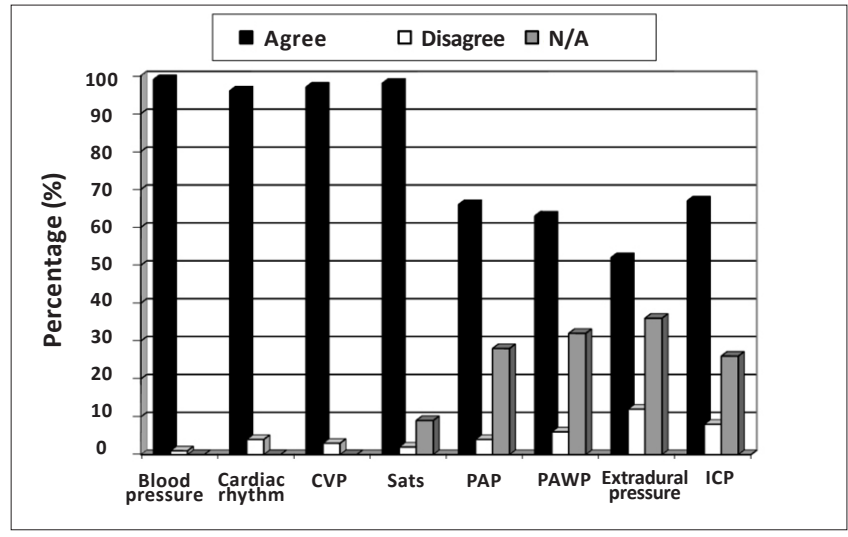

CVP, central venous pressure; Sats, oxygen saturation; PAP, pulmonary artery pressure; PAWP, pulmonary artery wedge pressure; ICP, intracranial pressure.

FIGURE 2: Perception regarding shift leaders' competence in using monitors for assessing patients $(n=98)$.

Of the 98 respondents, 59 indicated that they functioned as shift leaders in their units. This large element of selfevaluation is consistent with the standard $360^{\circ}$ method of performance appraisal used in nursing (Muller 2002:298-300). A total of $49 \%(n=29)$ of these respondents indicated that they worked as shift leaders between two and four times a week. Thirty-two per cent $(n=19)$ of them had between 5 and 9 years' experience in shift leading.

\section{Clinical competencies of the shift leader in the intensive care setting \\ Assessment}

Thorough knowledge regarding theoretical concepts and related sciences was classified as an essential competence by $71 \%(n=70)$ and $66 \%(n=65)$ of respondents, respectively.

Ninety-five per cent $(n=93)$ of respondents were of the opinion that the shift leaders in their respective units had the necessary knowledge of theoretical concepts and $96 \%$ $(n=94)$ of respondents viewed their shift leaders as competent in related sciences.

Some $68 \%$ of respondents $(n=67)$ indicated that the physical examination of a patient is an essential competence, $67 \%$ $(n=66)$ indicated that interpretation of laboratory results is an essential competence and $61 \%(n=60)$ saw the interpretation of a chest X-ray as essential.

A total of 92 respondents (94\%) felt that their shift leaders were competent in doing physical examinations of patients. Almost all respondents $(98 \%, n=96)$ perceived their shift leaders to be competent in interpreting laboratory results and $96 \%(n=94)$ regarded their shift leaders as competent in the interpretation of a chest X-rays.

Respondents classified patient hygiene, feeding status, and social and safety needs as essential, with respective scores of $78 \%(n=76), 79 \%(n=77), 83 \%(n=81)$ and $79 \%(n=77)$.

Most of the respondents $(96 \%, n=94)$ were of the opinion that their shift leaders were competent in assessing the hygiene needs of patients, while $98 \%(n=96)$ felt that their 


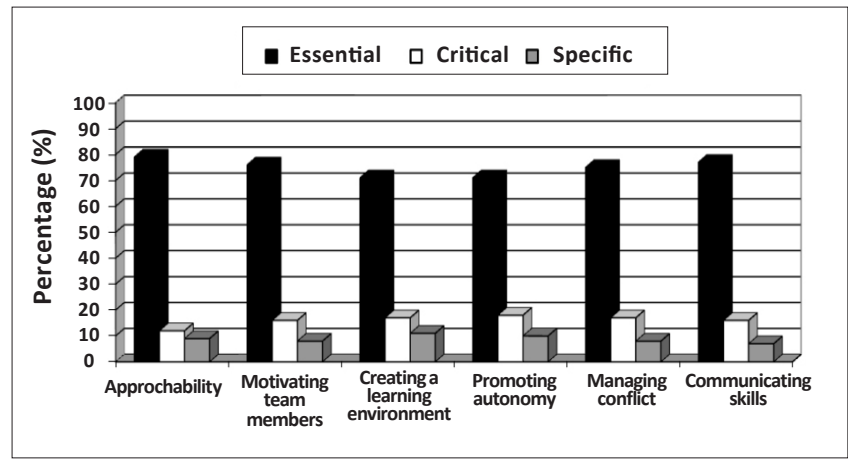

FIGURE 3: Leadership skills as essential competencies $(n=98)$.

shift leaders were competent in assessing the feeding status of patients. With regard to determining the social needs of patients, $98 \%$ of respondents $(n=96)$ indicated that the shift leaders were competent and $96 \%(n=94)$ felt that their shift leaders were competent in determining the safety needs of patients.

As shown in Figure 1, the following were classified as essential competencies by respondents: blood pressure $(61 \%, n=60)$, cardiac rhythm $(55 \%, n=54), \mathrm{CVP}(60 \%, n=59)$ and oxygen saturation $(63 \%, n=62)$. An equal number of respondents $(43 \%, n=42)$ classified the interpretation of pulmonary artery pressure (PAP) as an essential or specific competence.

Three items were classified as specific competencies. The interpretation of pulmonary artery wedge pressure (PAWP) was classified as specific by $47 \%(n=46)$ of respondents. Interpretation of extradural pressure and intracranial pressure (ICP) were classified as specific by $54 \%$ $(n=53)$ and $49 \%(n=48)$ of respondents, respectively.

As shown in Figure 2, respondents perceived their shift leaders to be competent in four assessments. Approximately two-thirds of respondents $(66 \%, n=65)$ classified the ability to use monitor readings to identify complications as an essential competence. Almost all respondents $(98 \%, n=96)$ indicated that their shift leaders could competently read monitors to indentify complications.

The respondents ( $n=98)$ were of the opinion that the need to stay abreast of the latest developments in intensive care nursing is an essential competence; $73 \%$ of respondents $(n=72)$ agreed with the statement that their shift leaders were keeping abreast of the latest developments in nursing, while the remaining $27 \%(n=26)$ disagreed.

The correct diagnosis of a patient after assessment was also indicated by $66 \%$ of the respondents $(n=65)$ as being an essential competence. It was classified as critical by $22 \%$ of respondents $(n=22)$ and $11 \%(n=11)$ classified it as specific to certain intensive care units. Almost all the respondents $(99 \%, n=97)$ regarded their shift leaders to be competent in diagnosing their patients correctly after the initial assessment. Only one respondent (1\%) disagreed.

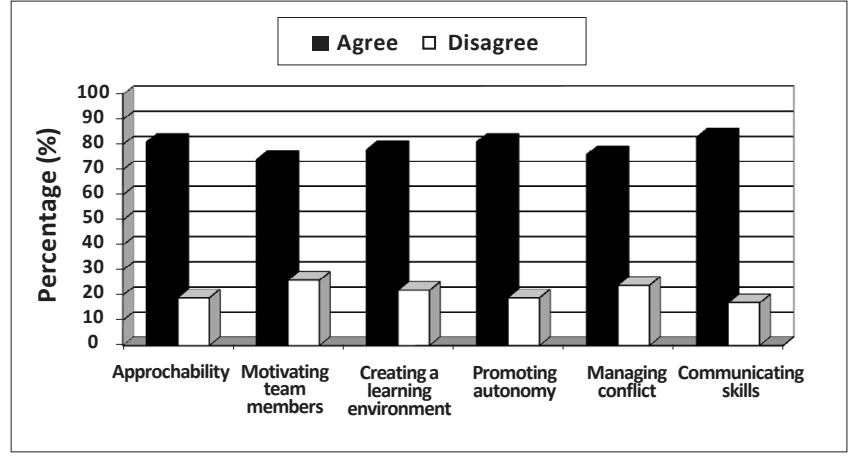

FIGURE 4: Competence in leadership skills $(n=98)$.

Respondents classified anticipation of a complication $(61 \%, n=60)$, its recognition $(64 \%, n=62)$ and subsequent removal of the cause $(61 \%, n=60)$ as essential competencies. Subsequently, 95\% $(n=93)$ agreed that their shift leaders were competent in anticipating problems, $94 \%(n=92)$ agreed that shift leaders could recognise the problem and $97 \%$ $(n=95)$ asserted that their shift leaders could remove the cause of the problem. Almost all $(99 \%, n=97)$ felt that their shift leaders could adequately maintain an open airway and $97 \%(n=95)$ agreed that shift leaders could adequately maintain circulation.

\section{Planning}

More than two-thirds of respondents $(68 \%, n=67)$ classified staff delegation at the start of a shift as an essential competence and $71 \%$ of respondents $(n=70)$ also classified planning the patient care as an essential competence. A similar percentage of the respondents $(69 \%, n=68)$ categorised prioritising any problems arising during planning patient care as an essential competence. Shift leaders were seen to be competent in delegating staff $(94 \%, n=92)$, planning patient care $(95 \%, n=93)$ and prioritising subsequent problems $(91 \%, n=92)$.

\section{Implementing}

Some $70 \%$ of the respondents $(n=69)$ classified the implementation of both the care plan and any medical regimen as essential competencies. Most of the respondents $(95 \%, n=93)$ indicated that their shift leaders were competent in implementing care plans and $98 \%$ $(n=96)$ agreed that their shift leaders were competent in implementing medical regimens.

Assisting with the insertion of CVP, pulmonary artery and arterial lines, as well as assisting with the removal of an intra-aortic balloon pump were regarded as essential competencies by $61 \%(n=60), 46 \%(n$ $=45), 58 \%(n=57)$ and $43 \%(n=42)$ of respondents respectively. A number of respondents classified assisting with the insertion of pulmonary artery lines (36\%, $n=35)$ and the removal of intra-aortic balloon pumps $(38 \%, n=37)$ as specific competencies.

Almost all respondents $(97 \%, n=95)$ reported that their shift leaders were competent in assisting doctors with the 
insertion of both CVP and arterial lines. Only 62\% of the respondents $(n=60)$ reported that their shift leaders were competent in assisting with the insertion of pulmonary artery lines, with $19 \%(n=19)$ indicating that this skill was not applicable to their unit. Seventy-three per cent $(n=70)$ agreed with the competence of their shift leaders in assisting with the removal of a balloon pump, while $14 \%$ of respondents $(n=14)$ indicated that this was not an applicable skill to their units.

A similar number of respondents $(65 \%, n=64$ and $64 \%$, $n=63$, respectively) indicated that implementation of an enteral feeding strategy and implementation of total parenteral nutrition may be classified as essential competencies. Almost all respondents $(99 \%, n=98)$ were of the opinion that their shift leaders were competent in implementing both enteral and parenteral feeding.

\section{Evaluating}

Evaluation of the patient's reaction to treatment after implementing the plan of care was regarded by $69 \%$ of respondents $(n=68)$ as an essential competence. Seventytwo per cent of respondents $(n=70)$ also classified shift leaders being aware of their own limitations and calling for assistance when they cannot solve a problem on their own as an essential competence.

Only $3 \%$ of respondents ( $n=3$ ) disagreed with the competence of their shift leaders in evaluating a patient's reaction to the care plan, while $97 \%(n=95)$ agreed that the shift leaders were competent. In the event of the shift leader being unable to solve a problem, $96 \%$ of respondents $(n=94)$ indicated that the shift leaders were competent in calling for assistance.

\section{Record keeping}

The majority of respondents $(74 \%, n=72)$ categorised knowing the criteria for good record keeping as an essential competence. The ability to maintain complete records was also classified by $77 \%$ of respondents $(n=75)$ as an essential competence. Almost all respondents $(95 \%, n=93)$ agreed that their shift leaders knew the criteria for good record keeping and $89 \%(n=87)$ agreed that their shift leaders kept complete records.

As shown in Figure 3, respondents felt that all leadership skills, namely approachability $(79 \%, n=77)$, motivation of team members $(76 \%, \mathrm{n}=74)$, creation of a learning environment $(71 \%, \mathrm{n}=70)$, promotion of autonomy amongst staff $(71 \%, \mathrm{n}=70)$, conflict management skills $(75 \%$, $\mathrm{n}=73)$ and communication skills $(77 \%, \mathrm{n}=75)$ were essential competencies.

As Figure 4 indicates, $81 \%$ of respondents $(n=79)$ agreed that their shift leaders were approachable and $74 \%(n=72)$ agreed that they motivated all members of the team. Shift leaders need to create a learning environment for staff members and $78 \%$ of respondents $(n=76)$ agreed that their shift leaders do. A large number of respondents $(81 \%, n=79)$ also felt that their shift leaders promoted autonomy among staff members. With regard to conflict
TABLE 3: Typology of competencies of shift leaders.

\begin{tabular}{|c|c|c|}
\hline Essential competencies & Critical competencies & Specific competencies \\
\hline$\sqrt{ }$ Knowledge of theoretical concepts & - & $\begin{array}{l}\sqrt{ } \text { Assessing readings } \\
\text { from monitors: }\end{array}$ \\
\hline$\sqrt{ }$ Knowledge of related sciences & - & \\
\hline $\begin{array}{l}\sqrt{ } \text { Initial assessments, including } \\
\text { physical examinations and } \\
\text { interpretation of laboratory results } \\
\text { and chest } X \text {-rays }\end{array}$ & - & PAP \\
\hline $\begin{array}{l}\sqrt{ } \text { Basic needs assessment, including } \\
\text { hygiene, feeding status, social needs } \\
\text { and safety }\end{array}$ & - & PAWP \\
\hline$\sqrt{ }$ Assessing readings from monitors: & - & $\begin{array}{l}\text { - Extradural } \\
\text { pressure }\end{array}$ \\
\hline - $\quad$ blood pressure & - & ICP \\
\hline - $\quad$ cardiac rhythm & - & \\
\hline$-\quad$ CVP & - & \\
\hline - Saturation & - & \\
\hline - $\quad$ PAP & - & \\
\hline $\begin{array}{l}\sqrt{ } \text { Recognising complications with the } \\
\text { help of monitor readings }\end{array}$ & - & \\
\hline $\begin{array}{l}\sqrt{ } \text { Keeping abreast of new } \\
\text { developments }\end{array}$ & - & \\
\hline$\sqrt{ }$ Correct diagnosis after assessment & - & \\
\hline $\begin{array}{l}\sqrt{ } \text { Dealing with life-threatening } \\
\text { conditions: }\end{array}$ & - & \\
\hline - $\quad$ anticipating problems & - & \\
\hline - recognising the cause & - & \\
\hline $\begin{array}{l}\sqrt{ } \text { Mobilising staffing and material } \\
\text { resources }\end{array}$ & - & \\
\hline $\begin{array}{l}\sqrt{ } \text { Implementing care plans and } \\
\text { medication regimens }\end{array}$ & - & \\
\hline$\sqrt{ }$ Communication: & - & \\
\hline - $\quad$ multidisciplinary team & - & \\
\hline - family of patients & - & \\
\hline$\sqrt{ }$ Assisting with advanced procedures: & - & \\
\hline - $\quad$ insertion of CVP lines & - & \\
\hline $\begin{array}{l}\text { insertion of pulmonary artery } \\
\text { lines }\end{array}$ & - & \\
\hline - insertion of arterial lines & - & \\
\hline $\begin{array}{l}\text { removal of an intra-aortic } \\
\text { balloon pump }\end{array}$ & - & \\
\hline$\sqrt{ }$ Advanced nursing procedures: & - & \\
\hline - haemodialysis & - & \\
\hline - $\quad$ adjusting ventilator settings & - & \\
\hline - $\quad$ removing sheaths & - & \\
\hline$\sqrt{ }$ Infection control: & - & \\
\hline - $\quad$ taking samples & - & \\
\hline - $\quad$ universal precautions & - & \\
\hline - hand-washing & - & \\
\hline - $\quad$ wound care & - & \\
\hline$\sqrt{ }$ Nutritional strategies: & - & \\
\hline - $\quad$ enteral feeding & - & \\
\hline - $\quad$ parenteral feeding & - & \\
\hline$\sqrt{ }$ Evaluating reaction to treatment & - & \\
\hline$\sqrt{ }$ Calling for assistance in good time & - & \\
\hline$\sqrt{ }$ Record keeping & - & \\
\hline$\sqrt{ }$ Leadership skills: & - & \\
\hline - $\quad$ approachability & - & \\
\hline - $\quad$ motivating team members & - & \\
\hline - $\quad$ creating a learning environment & - & \\
\hline - $\quad$ promoting autonomy & - & \\
\hline - $\quad$ managing conflict & - & \\
\hline - communication skills & - & \\
\hline$\sqrt{ }$ Ethical considerations: & - & \\
\hline - $\quad$ identifying organ donors & - & \\
\hline - $\quad$ assisting with brain death testing & - & \\
\hline $\begin{array}{l}\text { - protecting patients during } \\
\text { clinical trials }\end{array}$ & - & \\
\hline
\end{tabular}


management and communication skills, respondents felt that their shift leaders were competent, with 76\% $(n=74)$ and $83 \%$ $(n=80)$ agreeing with the respective statements.

The identification of organ donors was classified as an essential competence by $64 \%$ of the respondents $(n=63)$. Of the respondents, $26 \%(n=25)$ felt that this was a specific competency. This low figure may be explained by the type of intensive care units the respondents worked in.

Assisting the doctor during brain death was classified as an essential competence by $58 \%$ of respondents $(n=57)$. Since brain stem testing is used in the context of organ donation (Doran 2004:34), the type of intensive care units may once again explain why only $31 \%$ of respondents $(n=30)$ classified it as a specific competence. The protection of patients during clinical trials was deemed an essential competence by 68 respondents $(69 \%)$, while 20 respondents (21\%) deemed this a specific competence.

A large percentage of respondents $(70 \%, n=68)$ had the same opinion regarding the competence of their shift leaders in identifying potential organ donors. Four respondents (4\%) did not answer this question and indicated that it was not applicable to their units, despite this not being an option in the questionnaire. Most respondents $(75 \%, n=73)$ agreed that their shift leaders could assist doctors during brain death testing. Two respondents $(2 \%)$ stated that this question was not applicable to their units. Seventy-eight per cent of respondents $(n=76)$ were of the opinion that their shift leaders could protect patients during clinical trials. Once again, two respondents (2\%) stated that this was not applicable to their units.

A brief summary of these findings follows below.

- Respondents classified the majority of assessment functions as essential, except for assessment of PAP, PAWP, extradural pressure and ICP, which were classified as specific functions. All the shift leaders were also seen to be competent in these functions.

- Respondents classified all functions relating to diagnosis as essential and regarded their shift leaders as competent in these functions.

- Respondents classified all aspects of planning as essential and shift leaders were seen as competent.

- Respondents classified all the elements of implementation as essential. All shift leaders were seen as competent.

- Respondents classified all aspects of evaluation as essential and shift leaders were seen to be competent.

- Respondents classified all elements of record keeping as essential and reported their shift leaders to be competent.

- Respondents classified all aspects of leadership, as well as ethical practice, as essential and indicated that all their shift leaders were competent in dealing with these aspects.

\section{Limitations of the study}

Several obstacles were encountered during this study.

- Owing to fierce competition between hospital groups, this study could be conducted only within one private hospital group. The findings are therefore specific to this group and cannot be generalised.

- Feedback from some of the unit managers indicated resistance from staff to complete the questionnaire, since they did not want to sign consent for voluntary participation on the front page of the questionnaire, as required by the ethical committee of the University of Johannesburg.

\section{Recommendations}

\section{Further research}

- This study may be repeated to include all the South African private hospital groups or the public health sector. This will determine whether the results are specific to one group or can be generalised to all intensive care units, regardless of sector.

- Data may be used to formulate a unique scope of practice for nurses trained for intensive care in the South African context, since there is no scope of practice for registered nurses who hold additional qualifications (Schmollgruber 2007:247).

\section{Conclusion}

The study yielded the following conclusions.

- Respondents regarded all competencies as equally important. Although four competencies were identified as specific, all others were classified as essential. Respondents did not classify any competencies as critical.

- Table 3 shows a possible typology regarding the competencies of the shift leader in the intensive care unit.

\section{References}

Arries, E., 2002, "n Sisteem vir gehaltebesluitneming in verpleging' [No translation available], DCur proefskrif, Departement Verpleegkunde, Randse Afrikaanse Universiteit.

Arvidsson, B. \& Fridlund, B., 2005, 'Factors influencing nurse supervisor competence: A critical incident analysis study', Journal of Nursing Management 13, 231-237. doi:10.1111/j.1365-2834.2004.00532, xPMid:15819835

Bakalis, N.A., 2006, 'Clinical decision-making in cardiac nursing: A review of the literature', Nursing Standard 21(12), 39-46, PMid:1719538

Berggren, I., \& Severinsson, E., 2003, 'Nurse supervisors' actions in relation to their decision-making style and ethical approach to clinical supervision', Journal of Advanced Nursing 41(6), 615-622. doi:10.1046/j.1365-2648.2003.02573, xPMid:12622870

Berman, A., Snyder, S.J., Kozier, B. \& Erb, G., 2008, Kozier \& Erb's fundamentals of nursing. Concepts, process and practice, 8th edn., Pearson Prentice Hall, New Jersey.

Booyens, S.W., 2001, Introduction to health service management, Juta, Cape Town.

Burns, N. \& Grove, S.K., 2005, The practice of nursing research, Elsevier Saunders, Missouri.

Byers, J.F., 2004, 'Protecting patients during clinical research', Critical Care Nurse', 24(1), 53-59. PMid:15007893

Davidson, P.M., Elliott, D. \& Daly, J., 2006, 'Clinical leadership in contemporary clinical practice: Implications for nursing in Australia', Journal of Nursing Management 14, 180-187. doi:10.1111/j.1365-2934.2006.00555, xPMid:16600005

Denosa, 1998, Ethical standards for nurse researchers, DENOSA'S position statements, Pretoria.

Denosa, 2006, 'Where are the nurses?' Nursing Update, May, 42-45.

De Vos, A.S., 2002, Research at grass roots, Van Schaik, Pretoria.

Doran, M., 2004, 'The presence of family during brain stem death testing', Intensive and Critical Care Nursing, 20, 32-37. doi:10.1016/j.iccn.2003.10.003, PMid:14726251, doi:10.1016/j.iccn.2003.10.004, PMid:15072776

Elliott, D., Aitken, L. \& Chaboyer, W., 2007, ACCCN's critical care nursing, Elsevier, Marrickville. 
Hanley, E. \& Higgins, A., 2005, 'Assessment of clinical practice in intensive care: A review of the literature', Intensive and Critical Care Nursing 21, 268-275. doi:10.1016/j.iccn.2004.10.003, PMid:16182123, doi:10.1016/j.iccn.2004.10.004, PMid:16182124

Hoban, V., 2003, 'How to enhance your delegation skills', Nursing Times 99(13), 80-81. PMid:12715568

Huggins, K., 2004, 'Lifelong learning - the key to competence in the intensive care unit'? Intensive and Critical Care Nursing 20, 38-44. doi:10.1016/j. iccn.2003.10.001, PMid:14726252

Hughes, C. \& Kring, D., 2005, 'Consistent charge nurses improve teamwork', Nursing Management 36(10), 16. PMid:16210946

Ka Mzolo, B., 2005, 'Facing the music', Nursing Update, October, 26-29.

Krugman, M. \& Smith, V., 2003, 'Charge nurse leadership development and evaluation', Journal of Nursing Administration 33(5), 284-292. doi:10.1097/00005110200305000-00004

Le Blanc, P., De Jonge, J., De Rijk, A.E. \& Schaufeli, W.B., 2001, 'Well-being of intensive care nurses (WEBIC): A job analytic approach', Journal of Advanced Nursing 36(3), 460-470. doi:10.1046/j.1365-2648.2001.01994, xPMid:11686761

Locsin, R.C., 1998, 'Technologic competence as caring in critical care nursing', Holistic Nursing Practice 12(4), 50-56. PMid:9849208

Magobe, N.B.D., 2005, 'Guidelines to improve clinical competencies of learners of the programme - PHC: Clinical Nursing, Diagnosis, Treatment and Care', MCur the programme - PHC: Clinical Nursing, Diagnosis, Treatment and
dissertation, Department of Nursing, Randse Afrikaanse Universiteit.

Mathena, K.A., 2002, 'Nursing manager leadership skills', Journal of Nursing Administration 32(3), 136-142. doi:10.1097/00005110-200203000-00006

McOwen, A., Cooper, S. \& Clayworth, S., 2005, 'Are ward sisters and charge nurses able to fulfil their role'? Nursing Times 101(29), 38-41.

Meretoja, R., Isoaho, H. \& Leino-Kilpi, H., 2004, 'Nurse competence scale: Development and psychometric testing', Journal of Advanced Nursing 47(2), 124-133. doi:10.1 and psychometric testing', Journal of Advanced
Mollerup, A. \& Mortensen, P.S., 2004, 'Nurses' perceptions of their own level of competence', Connect 3(3), 70-73.

Morris, K., 2004, 'The role of the registered nurse as charge nurse', Ohio Nurses Review, 16

Muller, M., 2002, Nursing dynamics, 2nd edn., Heinemann, Sandown.

Nel, W.E. \& Uys, H.M.M., 1993, 'Pre-operatiewe rehabilitasie van koronêre vaatomleidingspasiënte', MCur dissertation, Department of Nursing, Randse Afrikaanse Universiteit.

Polit, D.F., Beck, C.T. \& Hungler, B.P., 2001, Essentials of nursing research, Lippincott, Philadelphia.

Rossouw, D., 2003, Intellectual tools - skills for the human sciences, Van Schaik, Pretoria.

Schmollgruber, S., 2007, 'Organisation, strengths and difficulties of South African intensive care nursing', Intensive and Critical Care Nursing 23, 247-248. doi:10.1016/j.iccn.2007.07.001, PMid:17720503

Scribante, J. \& Bhagwanjee, S., 2007, 'Intensive care nurse allocation in a cardiothoracic intensive care units: How many hands do we need?' Southern African Journal of Critical Care 23(2), 66-69.

Scribante, J., Schmollgruber, S. \& Nel, E., 2004, 'Perspectives on critical care nursing. South Africa', Connect 3(4), 111-115.

South African Nursing Council, 2004, Charter of Nursing Practice Draft 1, Pretoria.

Suominen, T., Savikko, N., Puukka, P., Doran, D.I. \& Leino-Kilpi, H., 2005, 'Work empowerment as experienced by head nurses', Journal of Nursing Management 13, 147-153. doi:10.1111/j.1365-2934.2004.00523, xPMid:15720484

Van Rooyen, D. \& Jordan, P.J. 2009, Foundation of nursing practice. Fundamentals of holistic care, African edn., Elsevier, Edinburgh. 